\title{
Vibrational analysis of $\mathrm{Ag}_{3}\left(\mathrm{PO}_{2} \mathrm{NH}\right)_{3}, \mathrm{Na}_{3}\left(\mathrm{PO}_{2} \mathrm{NH}\right)_{3} \cdot \mathrm{H}_{2} \mathrm{O}$, $\mathrm{Na}_{3}\left(\mathrm{PO}_{2} \mathrm{NH}\right)_{3} \cdot 4 \mathrm{H}_{2} \mathrm{O},\left[\mathrm{C}\left(\mathrm{NH}_{2}\right)_{3}\right]_{3}\left(\mathrm{PO}_{2} \mathrm{NH}\right)_{3} \cdot \mathrm{H}_{2} \mathrm{O}$ and $\left(\mathrm{NH}_{4}\right)_{4}\left(\mathrm{PO}_{2} \mathrm{NH}\right)_{4} \cdot 4 \mathrm{H}_{2} \mathrm{O}$
}

\author{
Annamma John ${ }^{\text {a }}$, Daizy Philip ${ }^{\mathrm{b}}$, Norbert Stock ${ }^{\mathrm{c}}$, Wolfgang Schnick ${ }^{\mathrm{c}}$, \\ S. Devanarayanan ${ }^{\mathrm{d}, *}$ \\ a Department of Physics, St. John's College, Anchal, Kollam 691 306, India \\ b Department of Physics, Mar Ivanios College, Thiruvananthapuram 695 015, India \\ c Laboratorium fur Anorganische Chemie der Universitat, D-95440 Bayreuth, Germany \\ d Department of Physics, University of Kerala, Kariavattom, Thiruvananthapuram 695 581, India
}

Received 31 July 2000; accepted 9 August 2000

\begin{abstract}
FT IR and FT Raman spectra of $\mathrm{Ag}_{3}\left(\mathrm{PO}_{2} \mathrm{NH}\right)$, (Compound I), $\mathrm{Na}_{3}\left(\mathrm{PO}_{2} \mathrm{NH}\right)_{3} \cdot \mathrm{H}_{2} \mathrm{O}$ (Compound II), $\mathrm{Na}_{3}\left(\mathrm{PO}_{2} \mathrm{NH}\right)_{3} \cdot 4 \mathrm{H}_{2} \mathrm{O}$ (Compound III), $\left[\mathrm{C}\left(\mathrm{NH}_{2}\right)_{3}\right]_{3}\left(\mathrm{PO}_{2} \mathrm{NH}\right)_{3} \cdot \mathrm{H}_{2} \mathrm{O}$ (Compound IV) and $\left(\mathrm{NH}_{4}\right)_{4}\left(\mathrm{PO}_{2} \mathrm{NH}_{4} \cdot 4 \mathrm{H}_{2} \mathrm{O}(\mathrm{Com}-\right.$ pound $\mathrm{V}$ ) are recorded and analyzed on the basis of the anions, cations and water molecules present in each of them. The $\mathrm{PO}_{2} \mathrm{NH}^{-}$anion ring in compound $\mathbf{I}$ is distorted due to the influence of $\mathrm{Ag}^{+}$cation. Wide variation in the hydrogen bond lengths in compound III is indicated by the splitting of the $v_{2}$ and $v_{3}$ modes of vibration of water molecules. The $\mathrm{NH}_{4}$ ion in compound $\mathbf{V}$ occupies lower site symmetry and exhibits hindered rotation in the lattice. The correlations between the symmetric and asymmetric stretching vibrations of $\mathrm{P}-\mathrm{N}-\mathrm{P}$ bridge and the $\mathrm{P}-\mathrm{N}-\mathrm{P}$ bond angle have also been discussed. (C) 2001 Elsevier Science B.V. All rights reserved.
\end{abstract}

Keywords: Infrared spectrum; Raman spectrum; Trimetaphosphimate; Tetrametaphosphimate; Hydrogen bonding

\section{Introduction}

Many salts of trimetaphosphimic acid and tetrametaphosphimic acid were known more than 100 years ago [1,2]. These compounds have been mainly characterized by IR spectroscopy $[3,4]$ and

\footnotetext{
* Corresponding author. Tel.: + 91-471-418920; fax: + 91471-307158.

E-mail address: phy@univker.ernet.in (S. Devanarayanan).
}

X-ray powder diffraction [5]. Extensive amount of work has been done on the study of the characteristic features of the coordination of metaphosphimate anions by vibrational spectroscopy, involving the calculation of wavenumbers and forms of the normal vibrations [6-16]. The trimetaphosphimate anion is a cyclic system formed by three regularly alternating slightly distorted $\mathrm{PO}_{2} \mathrm{NH}$ tetrahedra. The confirmation of the ring in the chair form with symmetry close to 
$\mathrm{C}_{3 \mathrm{v}}$ has been established by X-ray structure analysis [17] and from the vibrational spectra of alkali metal trimetaphosphimates [9]. From a study of the vibrational spectra it is known that the tetrametaphosphimate anion in solution has $\mathrm{S}_{4}$ symmetry and that in salts it has two kinds of structures, viz., $\mathrm{C}_{2 \mathrm{~h}}$ symmetry and $\mathrm{S}_{4}$ symmetry [14].

The present authors are interested in the study of the Raman and IR spectra of some newly synthesized phosphate compounds [18-20]. In this chapter a report of the analysis of both the IR and Raman spectra of $\mathrm{Ag}_{3}\left(\mathrm{PO}_{2} \mathrm{NH}\right)_{3}$ (hereafter referred as compound I), $\mathrm{Na}_{3}$ $\left(\mathrm{PO}_{2} \mathrm{NH}\right) 3 . \mathrm{H}_{2} \mathrm{O}$ (compound II), $\mathrm{Na}_{3}\left(\mathrm{PO}_{2} \mathrm{NH}_{3}\right.$ . $4 \mathrm{H}_{2} \mathrm{O}$ (compound III), $\left[\mathrm{C}\left(\mathrm{NH}_{2}\right)_{3}\right]_{3}\left(\mathrm{PO}_{2} \mathrm{NH}\right)_{3} \cdot \mathrm{H}_{2} \mathrm{O}$ (compound IV) and $\left(\mathrm{NH}_{4}\right)_{4}\left(\mathrm{PO}_{2} \mathrm{NH}\right)_{4} \cdot 4 \mathrm{H}_{2} \mathrm{O}$ (compound $\mathbf{V}$ ) is made. The Raman spectra of these samples in aqueous solution are also recorded to clear the ambiguity regarding certain vibrations.

\section{Experimental}

The starting material $\mathrm{Na}_{2}\left(\mathrm{PO}_{2} \mathrm{NH}\right)_{3} \cdot 4 \mathrm{H}_{2} \mathrm{O}$ (compound III) was prepared by the method reported by Olthof et al. [17]. To an acidified solution of this compound, an aqueous solution of $\mathrm{AgNO}_{3}$ is added to get $\mathrm{Ag}_{3}\left(\mathrm{PO}_{2} \mathrm{NH}\right)_{3}$ (compound I) [21]. $\mathrm{Na}_{3}\left(\mathrm{PO}_{2} \mathrm{NH}\right)_{3} \cdot \mathrm{H}_{2} \mathrm{O}$ (compound II) was obtained by vapour diffusion of $\mathrm{CH}_{3} \mathrm{CH}_{2} \mathrm{OH}$ at $363 \mathrm{~K}$ into a $3 \times 10^{-4} \mathrm{M}$ aqueous solution of the starting material [22]. $\left[\mathrm{C}\left(\mathrm{NH}_{2}\right)_{3}\right]_{3}\left(\mathrm{PO}_{2} \mathrm{NH}\right)_{3} \cdot \mathrm{H}_{2} \mathrm{O}$ (compound IV) was obtained by the addition of $\left[\mathrm{C}\left(\mathrm{NH}_{2}\right)_{3}\right]_{2} \mathrm{CO}_{3}$ to a freshly prepared solution of $\mathrm{H}_{3}\left(\mathrm{PO}_{2} \mathrm{NH}\right)_{3}$ [23]. For the preparation of

Table 1

Crystallographic datas of the five compounds

\begin{tabular}{lllll}
\hline Compounds & $\begin{array}{l}\text { Crystallo- } \\
\text { graphy }\end{array}$ & Space group & $\mathrm{Z}^{\mathrm{B}}$ & Refs. \\
\hline I & Monoclinic & $\mathrm{P} 2_{1} / \mathrm{c}\left(\mathrm{C}_{2 \mathrm{~h}}^{5}\right)$ & 4 & {$[21]$} \\
II & Monoclinic & $\mathrm{C} 2\left(\mathrm{C}_{2}^{3}\right)$ & 2 & {$[22]$} \\
III & Monoclinic & $\mathrm{P} 2_{1} / \mathrm{n}\left(\mathrm{C}_{2 \mathrm{~h}}^{5}\right)$ & 4 & {$[17]$} \\
IV & Orthorhombic & $\mathrm{Pbca}\left(\mathrm{D}_{2 \mathrm{~h}}^{15}\right)$ & 8 & {$[23]$} \\
V & Monoclinic & $\mathrm{P} 2_{1} / \mathrm{n}\left(\mathrm{C}_{2 \mathrm{~h}}^{5}\right)$ & 2 & {$[24]$} \\
\hline
\end{tabular}

$\left(\mathrm{NH}_{4}\right)_{4}\left(\mathrm{PO}_{2} \mathrm{NH}\right)_{4} \cdot 4 \mathrm{H}_{2} \mathrm{O}$ (compound $\mathrm{V}$ ), the starting material $\mathrm{H}_{4}\left(\mathrm{PO}_{2} \mathrm{NH}\right)_{4} \cdot 2 \mathrm{H}_{2} \mathrm{O}$ was obtained according to the literature [6] by hydrolysis $(333 \mathrm{~K}$, $48 \mathrm{~h})$ of $\left(\mathrm{PNCl}_{2}\right)$, in dioxane. Then an aqueous solution of ammonia (10\%) is added to a stoichiometric amount of the acid followed by precipitation with acetone [24].

The IR and Raman spectra were recorded using a Bruker IFS 66V FT-IR/FT-Raman Spectrometer. The Raman spectra were recorded with a resolution of $4 \mathrm{~cm}^{-1}$, using an Nd:YAG laser at wavelength $1.064 \mu \mathrm{m}$ and power $200 \mathrm{~mW}$, over the range $50-3500 \mathrm{~cm}^{-1}$. The IR spectra are obtained in the range $400-4000 \mathrm{~cm}^{-1}$ with the samples as $\mathrm{KBr}$ pellets using a globar source.

\section{Factor group analysis}

The compounds I, II, III and $\mathbf{V}$ crystallizes in the monoclinic system and compound IV is orthorhombic. The crystal symmetry data of all the five compounds used in the present work are tabulated in Table 1.

The cations, anions and water molecules in all the compounds occupy general position. The trimetaphosphimate anion $\left(\mathrm{PO}_{2} \mathrm{NH}\right)_{3}^{3-}$ and tetrametaphosphimate anion $\left(\mathrm{PO}_{2} \mathrm{NH}\right)_{4}^{4-}$ exhibit chair conformation, but in compound $\mathbf{I}$ the anion is markedly distorted because of the interaction between $\mathrm{Ag}^{+}$and one nitrogen atom of the anion [21]. The $\left(\mathrm{PO}_{2} \mathrm{NH}\right)_{3}^{3-}$ ring has $\mathrm{C}_{3 \mathrm{v}}$ symmetry [13] and the $\left(\mathrm{PO}_{2} \mathrm{NH}\right)_{4}^{4-}$ ring has $\mathrm{C}_{2 \mathrm{~h}}$ symmetry [15]. The cyclic anion rings in trimetaphosphimates are linked to one another by $\mathrm{N}-\mathrm{H}---\mathrm{O}$ hydrogen bonds to form pairs. These units are interconnected by $\mathrm{O}-\mathrm{H}---\mathrm{O}$ hydrogen bonds through water molecules forming columns. In compound $\mathbf{V}$ the tetrametaphosphimate rings are finked by $\mathrm{N}-\mathrm{H}---\mathrm{O}$ bonds forming column, along [100]. These columns are interconnected by $\mathrm{O}-\mathrm{H}---\mathrm{O}$ and $\mathrm{N}-\mathrm{H}---\mathrm{O}$ hydrogen bonds through water molecules and ammonium ions [21-24]. All $\mathrm{H}$ atoms are involved in hydrogen bonding. In II and III the sodium ions are approximately octahedrally coordinated by six oxygen atoms, either from the phosphonate groups or from the water 
molecules. The factor group analysis using the standard correlation method [25], for each compound gives the irreducible representation at $k=0$ as

\begin{tabular}{|c|c|}
\hline Compound I & $54 \mathrm{~A}_{\mathrm{g}}(\mathrm{R})+54 \mathrm{~B}_{\mathrm{g}}(\mathrm{R})+53 \mathrm{~A}_{\mathrm{u}}(\mathrm{IR})+52 \mathrm{~B}_{\mathrm{u}}(\mathrm{IR})$ \\
\hline Compound II & $62 \mathrm{~A}(\mathrm{R}, \mathrm{IR})+61 \mathrm{~B}(\mathrm{R}, \mathrm{IR})$ \\
\hline Compound III & $90 \mathrm{~A}_{\mathrm{g}}(\mathrm{R})+90 \mathrm{~B}_{\mathrm{g}}(\mathrm{R})+89 \mathrm{~A}_{\mathrm{u}}(\mathrm{IR})+88 \mathrm{~B}_{\mathrm{u}}(\mathrm{IR})$ \\
\hline Compound IV & $\begin{array}{l}144 \mathrm{~A}_{\mathrm{g}}(\mathrm{R})+144 \mathrm{~B}_{1 \mathrm{~g}}(\mathrm{R})+144 \mathrm{~B}_{2 \mathrm{~g}}(\mathrm{R}) \\
+144 \mathrm{~B}_{3 \mathrm{~g}}(\mathrm{R})+144 \mathrm{~A}_{\mathrm{u}}(\mathrm{O})+143 \mathrm{~B}_{1 \mathrm{u}}(\mathrm{IR}) \\
+143 \mathrm{~B}_{2 \mathrm{u}}(\mathrm{IR})+143 \mathrm{~B}_{3 \mathrm{u}}(\mathrm{IR})\end{array}$ \\
\hline Compound $\mathbf{V}$ & $78 \mathrm{~A}_{\mathrm{g}}(\mathrm{R})+78 \mathrm{~B}_{\mathrm{g}}(\mathrm{R})+77 \mathrm{~A}_{\mathrm{u}}(\mathrm{IR})+76 \mathrm{~B}_{\mathrm{u}}(\mathrm{IR})$ \\
\hline
\end{tabular}

\section{Results and discussions}

The IR and Raman spectra recorded for all the five compounds under investigation are shown in Figs. 1-3. The observed spectral lines and their assignments are given in Table 2.

\subsection{Vibrations of $\mathrm{PO}_{2} \mathrm{NH}^{-}$anion}

Analysis of the spectra obtained shows that $v \mathrm{NH}$ modes are highly characteristic. These are obtained as weak bands in Raman and medium to strong in IR around $3170 \mathrm{~cm}^{-1}$ in all the five compounds. The multiplicity of bands observed in compound I may be due to the participation of the $\mathrm{NH}$ groups in intramolecular and intermolecular hydrogen bonding [13]. The frequency shift observed in compound IV may be attributed to the overlapping of the $v \mathrm{NH}$ vibrations with that of $v \mathrm{NH}_{2}$ vibrations. The $\mathrm{NH}$ deformations are observed in the region 13901322 and $781-723 \mathrm{~cm}^{-1}$.

As expected the asymmetric and symmetric stretching vibrations of $\mathrm{PO}_{2}$ group are observed in the region $1241-1141$ and $1118-1039 \mathrm{~cm}^{-1}$ respectively [26]. The asymmetric modes are very strong in the IR spectrum and the symmetric modes are very strong in the Raman spectrum. Both the asymmetric and symmetric stretching modes of $\mathrm{PO}_{2}$ in compound $\mathbf{V}$ appear a little lower in frequency when compared to all the other four compounds. This is due to the greater value of the average $\mathrm{P}-\mathrm{O}$ bond length in compound $\mathbf{V}$ than that in all the other compounds [24]. The bending modes of $\mathrm{PO}_{2}$ group are observed around $600 \mathrm{~cm}^{-1}$. The wagging, rocking and twisting modes of $\mathrm{PO}_{2}$ group are also assigned (Table 2).

The ring vibrations of the anion - the antisymmetric and symmetric stretches of $\mathrm{P}-\mathrm{NH}-\mathrm{P}$ bridges are expected in the region 1000-800 $\mathrm{cm}^{-1}$ and the ring breathing vibration around $400 \mathrm{~cm}^{-1}[12,15]$. In compound I the asymmetric stretching gives very weak Raman bands at 971 and $937 \mathrm{~cm}^{-1}$ and the symmetric stretching bands are observed at 831 and $793 \mathrm{~cm}^{-1}$. The corresponding IR bands are singlets observed at 933 and $813 \mathrm{~cm}^{-1}$ respectively. The large splitting $\left(\approx 138 \mathrm{~cm}^{-1}\right)$ of the symmetric mode observed in the Raman spectrum confirms the distortion of the $\mathrm{PO}_{2} \mathrm{NH}^{-}$anion ring due to the influence of the stronger $\mathrm{Ag}^{+}$cation on the anion structure [21]. In the Raman spectrum of compound $\mathbf{V}$, a weak band is observed at 1008 $\mathrm{cm}^{-1}$. Sukova et al. [15], in their studies on lanthanum and lanthanide tetrametaphosphimate had assigned the strong IR band around $\approx 1005$ $\mathrm{cm}^{-1}$ to $v_{\text {as }} \mathrm{P}-\mathrm{NH}-\mathrm{P}$ along with its components in the region $980-900 \mathrm{~cm}^{-1}$. Accordingly the Raman band at $1008 \mathrm{~cm}^{-1}$, in the present study, is assigned to $v_{\text {as }} \mathrm{P}-\mathrm{NH}-\mathrm{P}$. Its components are the very weak bands at 980-910 $\mathrm{cm}^{-1}$.

The corresponding IR. bands are very strong at 992 and $955 \mathrm{~cm}^{-1}$. The weak to medium intensity Raman bands around $493 \mathrm{~cm}^{-1}$ are due to the ring breathing vibrations. The IR spectra show medium to strong intensity bands in this region. The external deformation mode is assigned to the weak bands around $225 \mathrm{~cm}^{-1}$ $[9,12]$.

\subsection{Vibrations of $\mathrm{NH}_{4}^{+}$cation}

The normal modes of vibration of free $\mathrm{NH}_{4}^{+}$ ion under perfect $\mathrm{T}_{\mathrm{d}}$ symmetry have frequencies of $3033,1685,3134$ and $1397 \mathrm{~cm}^{-1}$ for $v_{1}\left(\mathrm{~A}_{1}\right)$, $v_{2}(\mathrm{E}), v_{3}\left(\mathrm{~F}_{2}\right)$ and $v_{4}\left(\mathrm{~F}_{2}\right)$ modes, respectively [26]. 


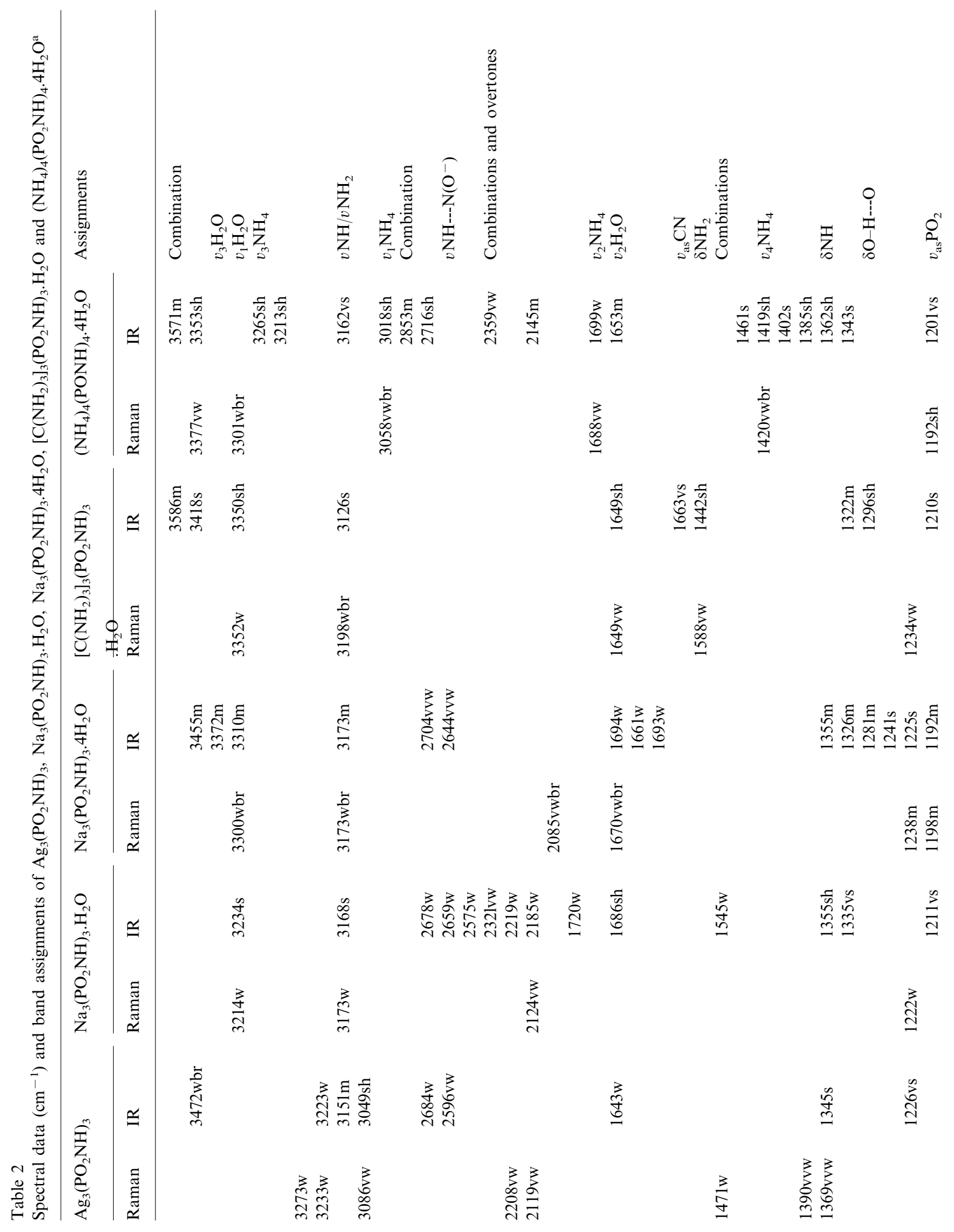




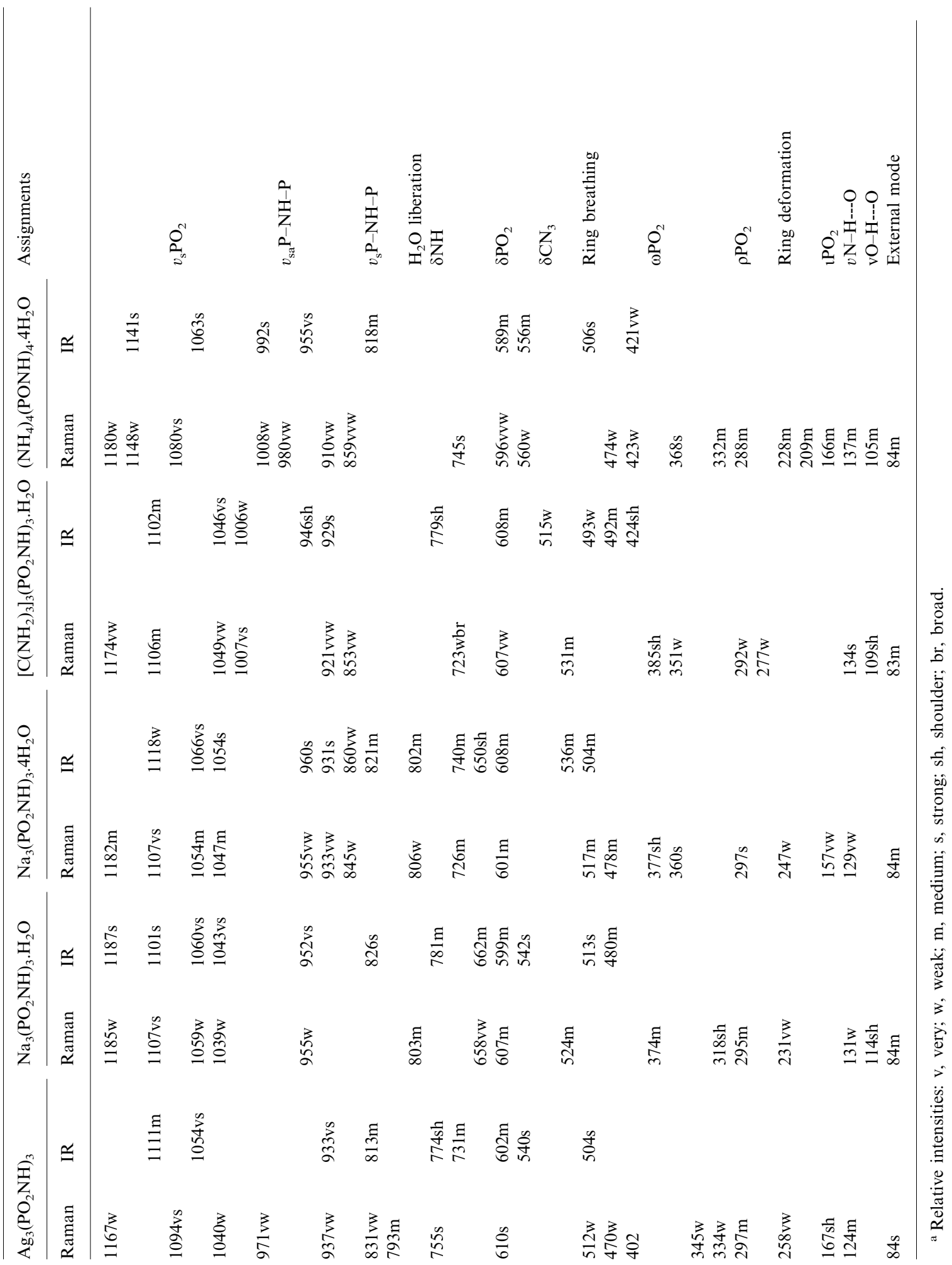




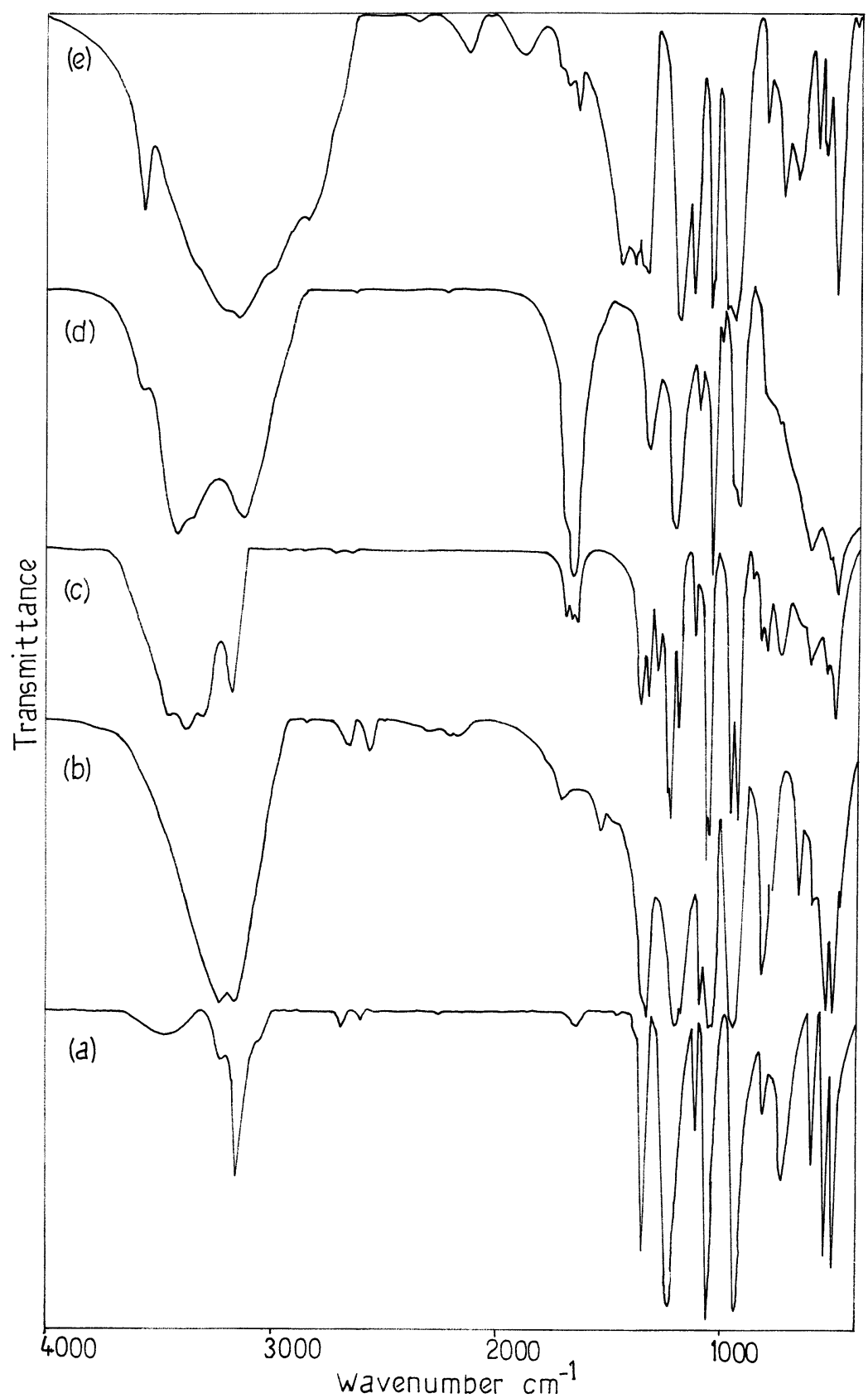

Fig. 1. FT IR spectra of (a) $\mathrm{Ag}_{3}\left(\mathrm{PO}_{2} \mathrm{NH}\right)_{3}$, (b) $\mathrm{Na}_{3}\left(\mathrm{PO}_{2} \mathrm{NH}\right)_{3} \cdot \mathrm{H}_{2} \mathrm{O}$ (c) $\mathrm{Na}_{3}\left(\mathrm{PO}_{2} \mathrm{NH}\right)_{3} \cdot 4 \mathrm{H}_{2} \mathrm{O}$, (d) $\left[\mathrm{C}(\mathrm{NH})_{3}\right]_{3}\left(\mathrm{PO}_{2} \mathrm{NH}_{3} \cdot \mathrm{H}_{2} \mathrm{O}\right.$ and (e) $\left(\mathrm{NH}_{4}\right)_{4}\left(\mathrm{PO}_{2} \mathrm{NH}\right)_{4} \cdot 4 \mathrm{H}_{2} \mathrm{O}$ in the region $400-4000 \mathrm{~cm}^{-1}$.

All the four modes are Raman active whereas $v_{1}$ and $v_{2}$ are IR inactive. In the crystal, the ion occupies a lower site symmetry, which may lead to the activation of inactive modes, splitting of degenerate modes and shifting of fundamental modes. 
In the Raman spectrum of compound $\mathbf{V}$, the weak broad band at $3058 \mathrm{~cm}^{-1}$ is assigned to the symmetric stretching mode $v_{1}$. The corresponding IR band appears as a shoulder at 3018 $\mathrm{cm}^{-1}$. The broadening $\left(\approx 250 \mathrm{~cm}^{-1}\right)$ of the $v_{1}$ mode indicate the participation of the $\mathrm{NH}_{4}$ ions in the formation of different types of hydrogen bonds $\mathrm{N}-\mathrm{H}---\mathrm{N}$ and $\mathrm{N}-\mathrm{H}---\mathrm{O}$ of varying strength [27]. The struc-tural investigation of compound $\mathbf{V}$ [24] reports that the $\mathrm{NH}_{4}$ ions take part in extended hydrogen bonding by bridging, via, the lone pairs of OW2, N4-H42--OW2---H31-N3 (N---O---N 2.801, $2.858 \AA$ ). The observation of strong IR band extending from about 3700 to $2700 \mathrm{~cm}^{-1}\left(\mathrm{FWHM} \approx 720 \mathrm{~cm}^{-1}\right.$ ) also supports this. The absorption shoulders at
3265 and $3213 \mathrm{~cm}^{-1}$ are due to the triply degenerate asymmetric stretching mode $v_{3}$. The $v_{2}$ mode is observed as weak absorption band at $1699 \mathrm{~cm}^{-1}$. The very weak Raman band at $1688 \mathrm{~cm}^{-1}$ is the counterpart of this mode. The absorption triplet at 1461,1419 and $1402 \mathrm{~cm}^{-1}$ are due to the triply degenerate $v_{4}$ mode of the ammonium ion.

The splitting of the $v_{3}$ and $v_{4}$ mode and the activation of the IR inactive modes $v_{1}$ and $v_{2}$ supports the lowering of site symmetry $\left(\mathrm{C}_{1}\right)$ of the ion. All the four modes of the $\mathrm{NH}_{4}$ ion are found to be shifted from the free state values. This observation, in agreement with the structural reports, shows that the ion is distorted from the ideal tetrahedral geometry [24].

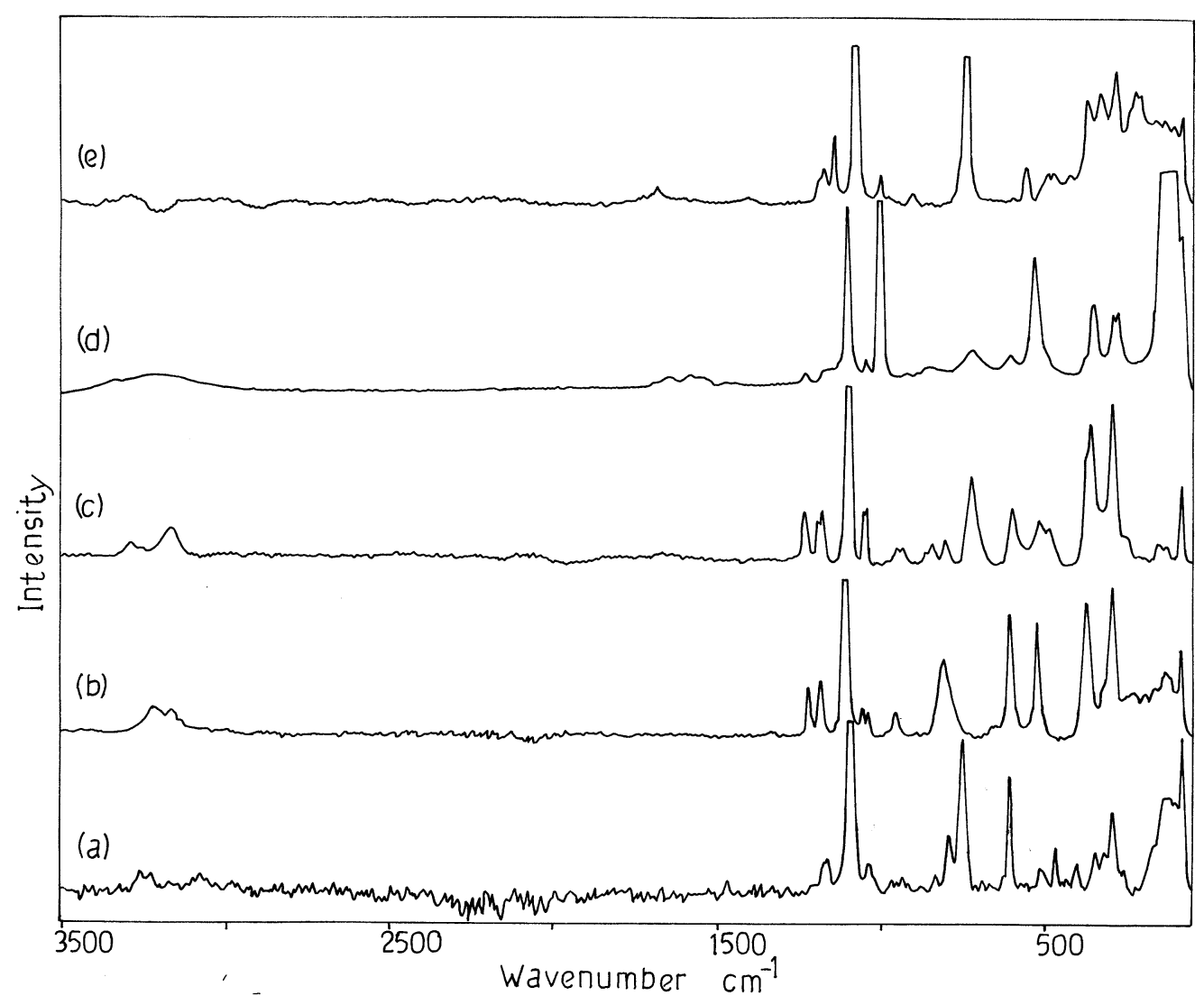

Fig. 2. FT Raman spectra of (a) $\mathrm{Ag}_{3}\left(\mathrm{PO}_{2} \mathrm{NH}\right)_{3}$, (b) $\mathrm{Na}_{3}\left(\mathrm{PO}_{2} \mathrm{NH}\right)_{3} \cdot \mathrm{H}_{2} \mathrm{O}$ (c) $\mathrm{Na}_{3}\left(\mathrm{PO}_{2} \mathrm{NH}_{3} \cdot 4 \mathrm{H}_{2} \mathrm{O},(\mathrm{d})\left[\mathrm{C}\left(\mathrm{NH}_{2}\right)_{3}\right]_{3}\left(\mathrm{PO} \mathrm{NH}_{3} \cdot \mathrm{H}_{2} \mathrm{O}\right.\right.$ and (e) $\left(\mathrm{NH}_{4}\right)_{4}\left(\mathrm{PO}_{2} \mathrm{NH}\right) \cdot 4 \mathrm{H}_{2} \mathrm{O}$ in the region $50-3500 \mathrm{~cm}^{-1}$. 


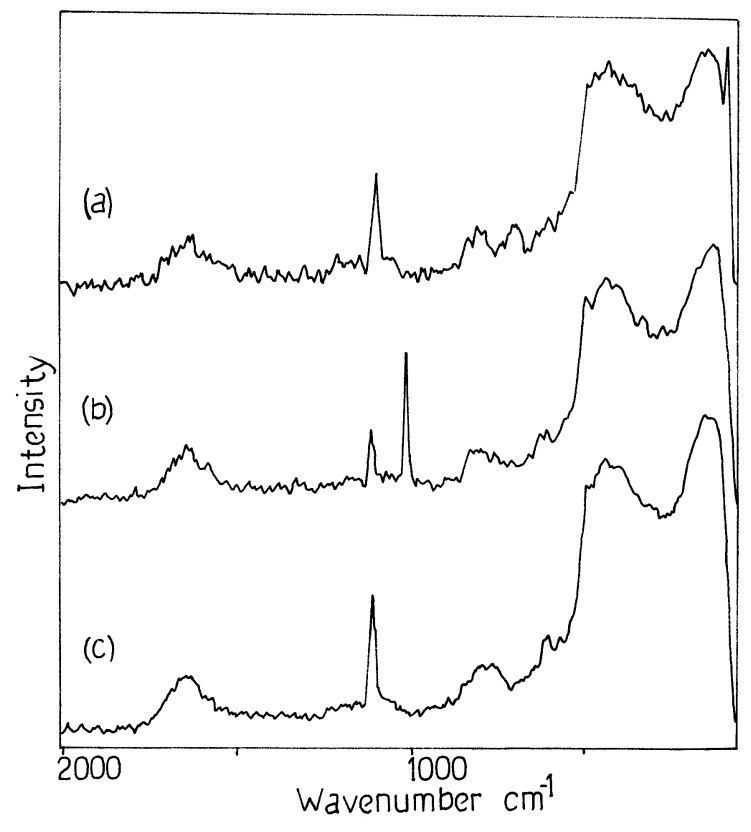

Fig. 3. FT Raman spectra of the aqueous solution of (a) $\mathrm{Na}_{3}\left(\mathrm{PO}_{3} \mathrm{NH}\right)_{3} \cdot \mathrm{H}_{2} \mathrm{O}$ (b) $\left[\mathrm{C}\left(\mathrm{NH}_{2}\right)_{3}\right]_{3}\left(\mathrm{PO}_{2} \mathrm{NH}\right)_{3} \cdot \mathrm{H}_{2} \mathrm{O}$ and (c) $\left(\mathrm{NH}_{4}\right)_{4}\left(\mathrm{PO}_{2} \mathrm{NH}\right)_{4} \cdot 4 \mathrm{H}_{2} \mathrm{O}$ in the region $50-2000 \mathrm{~cm}^{-1}$.

In a freely rotating $\mathrm{NH}_{4}$ ion, the $v_{3}$ and $v_{4}$ modes are triply degenerate. However if it is in the locked-in position in the crystal lattice, the degeneracy is expected to be lifted [28]. In the present study, the removal of degeneracy of the $v_{3}$ and $v_{4}$ modes suggests that the ion is probably in a locked in position in the crystal lattice. The fundamental $v_{6}$ could not be identified independently as it merges in the region of the bending mode of $\mathrm{PO}_{2}$. However, its combinations $v_{2}+v_{6}$ and $v_{4}+v_{6}$ are not observed. Hence it may be inferred that the $\mathrm{NH}_{4}$ ion is executing hindered rotation in the lattice [29-32].

\subsection{Vibrations of $\left[\mathrm{C}\left(\mathrm{NH}_{2}\right)_{3}\right]^{+}$cation}

In the structural studies of triguanidinium tri- $\mu$ imido-cyclotriphosphate monohydrate (compound IV) Stock et al. have assigned highly intense IR band at $1662 \mathrm{~cm}^{-1}$ to the asymmetric $\mathrm{CN}$ stretching vibrations. The IR spectrum of tetraguanidinium tetra- $\mu$-imido-cyclotetraphosphate tetrahydrate $\left[\mathrm{C}\left(\mathrm{NH}_{2}\right)_{3}\right]_{4}\left(\mathrm{PO}_{2} \mathrm{NH}\right)_{4} \cdot 4 \mathrm{H}_{2} \mathrm{O}$ also shows a highly intense IR band at $1659 \mathrm{~cm}^{-1}$ due to $v_{\text {as }} \mathrm{CN}$ [28]. In the present investigation, the very strong absorption band at $1663 \mathrm{~cm}^{-1}$ is assigned to the asymmetric $\mathrm{CN}$ stretching vibrations. The very high intensity of this band differentiate it from the $v_{2}$ mode of water molecules, which are usually weak to moderate in IR. The symmetric CN stretching is very strong in Raman at $1007 \mathrm{~cm}^{-1}$. Its corresponding IR band is weak at $1006 \mathrm{~cm}^{-1}$. The high intensity of this band in the Raman spectra and the low intensity in the IR spectra, differentiate it from the $v_{\text {as }} \mathrm{P}-\mathrm{NH}-\mathrm{P}$ mode, which is usually weak in Raman and intense in IR. The Raman spectrum of the aqueous solution also shows, this intense band without much shift $\left(1010 \mathrm{~cm}^{-1}\right)$, which support our assignment of $v_{\mathrm{s}} \mathrm{CN}$. The deformation of $\mathrm{CN}_{3}$ gives a weak band at $515 \mathrm{~cm}^{-1}$. The $v \mathrm{NH}_{2}$ mode is masked in the broad bands of $v \mathrm{NH}$. However, the bands of $\mathrm{NH}_{2}$ deformation are clearly identifiable. The weak Raman band at $1588 \mathrm{~cm}^{-1}$ and the shoulder at $1542 \mathrm{~cm}^{-1}$ in the IR spectrum are due to the $\delta \mathrm{NH}_{2}$ vibration.

\subsection{Vibrations of water molecules}

The $v_{1}$ and $v_{3}$ modes of water molecules are observed in the region $3472-3214 \mathrm{~cm}^{-1}$ and the bending mode $v_{2}$ around $1661 \mathrm{~cm}^{-1}$. The existence of broad overlapping bands in the stretching region shows the presence of both weakly and strongly bonded molecules of water of crystallization and of hydrogen bridges with different bond energies. The absorption band at 3472 and 1643 $\mathrm{cm}^{-1}$ in the unhydrated compound $\mathbf{I}$ are due to the water molecules adsorbed during pelletization. In the IR spectrum of compound III the $v_{3}$ mode of $\mathrm{H}_{2} \mathrm{O}$ appear as a doublet at 3455 and 3372 $\mathrm{cm}^{-1}$ and the $v_{2}$ mode as triplet at 1694, 1661 and $1639 \mathrm{~cm}^{-1}$. This splitting of the fundamental vibrations are due to the wide variation in the hydrogen bond lengths, where the $\mathrm{O}---\mathrm{O}$ ranges from 2.821 to $4.144 \AA$ [17]. The librational modes of $\mathrm{H}_{2} \mathrm{O}$ are observed as weak to medium intense bands in the region $806-802 \mathrm{~cm}^{-1}$. This assign- 
ment is confirmed by the broad bands observed about this region in their solution spectra.

\subsection{Hydrogen bonding}

Structural investigations report that, in all the five compounds investigated, two anion rings are linked to each other by $\mathrm{N}-\mathrm{H}---\mathrm{O}$ hydrogen bonds forming pairs [17,21-24]. These units are interconnected by $\mathrm{O}-\mathrm{H}---\mathrm{O}$ hydrogen bonds through water molecules.

As a result of the comparison of the spectra of tetrametaphosphimates with $\mathrm{NH}$ group in the ring, with the spectrum of octa silver salt $\mathrm{Ag}_{\mathrm{g}}$ $\left(\mathrm{PO}_{2} \mathrm{~N}\right)_{4}$, Lunkwitz and Steger [7] were able to distinguish two bands at 3075 and $2675 \mathrm{~cm}^{-1}$ corresponding only to $\mathrm{NH}$ groups and bridging hydrogen bonds $\mathrm{NH}---\mathrm{N}\left(\mathrm{O}^{-}\right)$, respectively. The weak absorption bands in the region 2716-2575 $\mathrm{cm}^{-1}$ are accordingly assigned to $\mathrm{NH} . . . \mathrm{N}\left(\mathrm{O}^{-}\right)$ vibrations.

\subsection{Correlation between the $P-N-P$ stretching} vibrations and the $P-N-P$ angle

The correlation between the $\mathrm{P}-\mathrm{O}-\mathrm{P}$ angle and the asymmetric and symmetric stretching frequencies of the $\mathrm{P}-\mathrm{O}-\mathrm{P}$ bridge are well known [33-37]. The correlation exhibits a definite pattern of relationship. Several authors have used these correlations to calculate the unknown $\mathrm{P}-\mathrm{O}-\mathrm{P}$ angles in pyrophosphates [36,37] and cyclohexaphosphates [19]. Lazarev, [37] has used similar type of correlations in pyrosilicates and determined the $\mathrm{Si}-\mathrm{O}-\mathrm{Si}$ angles.

In the present investigation, a similar type of correlation is attempted for the $\mathrm{P}-\mathrm{N}-\mathrm{P}$ group. The structural and spectral data used are listed in Table 3. The curves (Fig. 4) are plotted for the two relationships

1. $v_{\text {as }} \mathrm{PNP}-v_{\text {as }} \mathrm{PNP}=f_{1}(\angle \mathrm{PNP})$

2. $\left(v_{\mathrm{as}} \mathrm{PNP}-v_{\mathrm{s}} \mathrm{PNP}\right) /\left(v_{\mathrm{as}} \mathrm{PNP}+v_{\mathrm{s}} \mathrm{PNP}\right)$ $=f_{2}(\angle \mathrm{PNP})$

The curves show a definite pattern as in the case of POP bridge.

Table 3

Correlation between the PNP bridge angle and its stretching vibrations

\begin{tabular}{|c|c|c|c|c|c|c|}
\hline Compound & $\begin{array}{l}v_{\text {as }} \mathrm{PNP} \\
\left(\mathrm{cm}^{-1}\right)\end{array}$ & $\begin{array}{l}v_{\mathrm{s}} \mathrm{PNP} \\
\left(\mathrm{cm}^{-1}\right)\end{array}$ & $\begin{array}{l}v_{\mathrm{as}}-v_{\mathrm{s}} \\
\left(\mathrm{cm}^{-1}\right)\end{array}$ & $\begin{array}{l}\left(v_{\text {as }}-v_{\mathrm{s}}\right) / \\
\left(v_{\text {as }}+v_{\mathrm{s}}\right)\end{array}$ & $\begin{array}{l}\angle \mathrm{PNP} \\
\left({ }^{\circ}\right)\end{array}$ & Refs. \\
\hline $\mathrm{Ag}_{3}\left(\mathrm{PO}_{2} \mathrm{NH}\right)_{3}$ & 933 & 813 & 120 & 0.0687 & 125.5 & [21]; present work \\
\hline $\mathrm{Na}_{3}\left(\mathrm{PO}_{2} \mathrm{NH}\right)_{3} \cdot \mathrm{H}_{2} \mathrm{O}$ & 952 & 826 & 126 & 0.0709 & 124.3 & [22]; present work \\
\hline $\mathrm{Na}_{3}\left(\mathrm{PO}_{2} \mathrm{NH}\right)_{3} \cdot 4 \mathrm{H}_{2} \mathrm{O}$ & $\begin{array}{l}960 \\
931\end{array}$ & $\begin{array}{l}860 \\
821 \\
802\end{array}$ & $\begin{array}{l}100 \\
110 \\
129\end{array}$ & $\begin{array}{l}0.0549 \\
0.0628 \\
0.0744\end{array}$ & $\begin{array}{l}121.0 \\
122.6 \\
124.4\end{array}$ & [17]; present work \\
\hline$\left[\mathrm{C}\left(\mathrm{NH}_{2}\right)_{3}\right]_{3}\left(\mathrm{PO}_{2} \mathrm{NH}\right)_{3} \cdot \mathrm{H}_{2} \mathrm{O}$ & 921 & 853 & 68 & 0.0373 & 122.1 & [23]; present work \\
\hline$\left(\mathrm{NH}_{4}\right)_{4}\left(\mathrm{PO}_{2} \mathrm{NH}\right)_{4} \cdot 4 \mathrm{H}_{2} \mathrm{O}$ & $\begin{array}{l}992 \\
955\end{array}$ & 818 & $\begin{array}{l}137 \\
174\end{array}$ & $\begin{array}{l}0.0773 \\
0.0961\end{array}$ & $\begin{array}{l}128.61 \\
130.1\end{array}$ & [24]; present work \\
\hline $\mathrm{Rh}\left(\mathrm{PO}_{2} \mathrm{NH}\right)_{3}\left(\mathrm{NH}_{3}\right)_{3} \cdot \mathrm{H}_{2} \mathrm{O}$ & 935 & 870 & 65 & 0.03601 & 121 & {$[16]$} \\
\hline $\mathrm{Na}_{4}\left\{\mathrm{Cu}\left[\left(\mathrm{PO}_{2} \mathrm{NH}\right)_{3}\right]_{2}\right\} \cdot 10 \mathrm{H}_{2} \mathrm{O}$ & $\begin{array}{l}960 \\
930\end{array}$ & $\begin{array}{l}820 \\
800\end{array}$ & $\begin{array}{l}110 \\
160\end{array}$ & $\begin{array}{l}0.0628 \\
0.0909\end{array}$ & $\begin{array}{l}122 \\
133\end{array}$ & {$[15]$} \\
\hline$\left[\mathrm{C}\left(\mathrm{NH}_{2}\right)_{3}\right]_{4}\left(\mathrm{PO}_{2} \mathrm{NH}\right)_{4} \cdot 4 \mathrm{H}_{2} \mathrm{O}$ & $\begin{array}{l}976 \\
941\end{array}$ & $\begin{array}{l}820 \\
773\end{array}$ & $\begin{array}{l}121 \\
156\end{array}$ & $\begin{array}{l}0.0687 \\
0.0869\end{array}$ & $\begin{array}{l}123 \\
130\end{array}$ & {$[23]$} \\
\hline
\end{tabular}



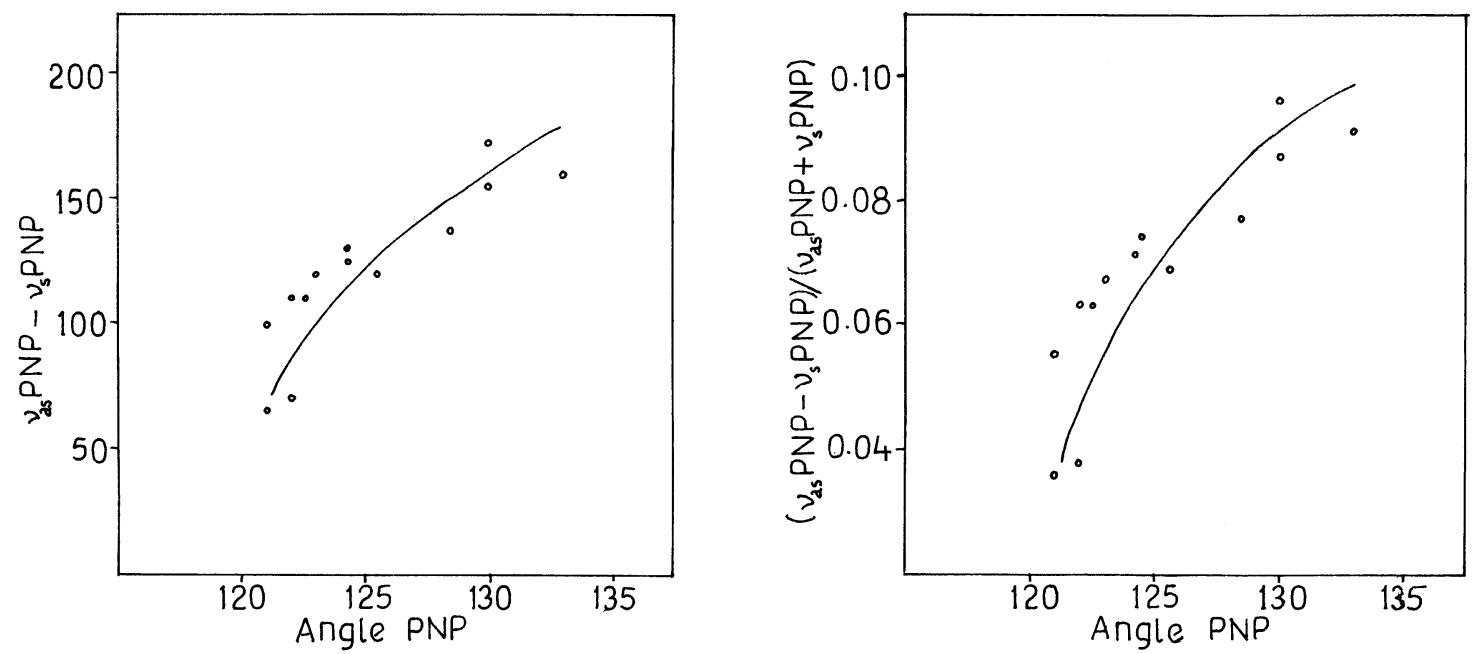

Fig. 4. Relationship between (a) the angle $\mathrm{PNP}$ and $v_{\text {as }} \mathrm{PNP}-v_{\mathrm{s}} \mathrm{PNP}$ and (b) the angle $\mathrm{PNP}$ and $\left(v_{\text {as }} \mathrm{PNP}-v_{\mathrm{s}} \mathrm{PNP}\right) /\left(v_{\text {as }} \mathrm{PNP}+\right.$ $\left.v_{\mathrm{s}} \mathrm{PNP}\right)$.

\section{Conclusions}

The large splitting of vs. $\mathrm{P}-\mathrm{NH}-\mathrm{P}$ modes in compound $\mathrm{I}$ indicates distortion of the $\mathrm{PO}_{2} \mathrm{NH}^{-}$ anion ring due to the influence of $\mathrm{Ag}^{+}$cation. $\mathrm{NH}_{4}^{+}$ ion exhibits hindered rotation in the lattice. The lifting up of the degeneracy of $v_{3}$ and $v_{4}$ mode and the activation of the IR inactive modes indicates lower site symmetry of the NH, ion. Splitting of the $v_{2}$ and $v_{3}$ modes of vibration of water molecules in compound III indicates the wide variation in the hydrogen bond lengths. The correlation between angle $\mathrm{P}-\mathrm{N}-\mathrm{P}$ and the stretching vibrations of the $\mathrm{P}-\mathrm{N}-\mathrm{P}$ bridge exhibit a definite pattern.

\section{References}

[1] H.N. Stokes, Ber. Dtsch. Chem. Ges. 28 (1895) 437.

[2] H.N. Stokes, Am. Chem. J. 18 (1896) 629.

[3] D.E.C. Corbridge, E.J. Lowe, J. Chem. Soc. (1954) 4555.

[4] J.V. Pustinger, W.T. Cave, M.L. Nielsen, Spectrochim. Acta 11 (1959) 909.

[5] A.H. Herzog, M.L. Nielsen, Anal. Chem. 30 (1958) 1490.

[6] E. Steger, K. Lunkwitz, Z. Anorg. Allgem. Chem. 313 (1961) 262.

[7] E. Steger, K. Lunkwitz, Z. Anorg. Allgem. Chem. 313 (1961) 271.
[8] E. Steger, K. Lunkwitz, Z. Anorg. Allgem. Chem. 316 (1962) 293.

[9] K. Lunkwitz, E. Steger, Spectrochim. Acta 23A (1967) 2593.

[10] K. Lunkwitz, E. Steger, Wiss. Z. Techn. Univ. Dresden 17 (1968) 1459.

[11] K. Lunkwitz, E. Steger, Z. Anorg. Allgem. Chem. 358 (1968) 111.

[12] E. Steger, K. Lunkwitz, J. Mol. Struct. 3 (1969) 67.

[13] L.M. Sukova, O.I. Kondratov, K.I. Petrova, I.A. Rozanov, Sov. J. Coord. Chem. 3 (1977) 850.

[14] L.M. Sukova, K.I. Petrova, I.A. Rozanov, D.A. Murashov, Russ. J. Inorg. Chem. 24 (1979) 1328.

[15] L.M. Sukova, O.I. Kondratov, K.I. Petrova, I.A. Rozanov, G.G. Novitskii, Russ. J. Inorg. Chem. 24 (1979) 1354.

[16] L.M. Sukova, O.I. Kondratov, K.I. Petrova, I.A. Rozanov, G.G. Novitskii, Russ. J. Inorg. Chem. 24 (1979) 1509.

[17] R. Olthof, T. Migchelsen, A. Vos, Acta Cryst. 19 (1965) 596.

[18] A. John, S. Devanarayanan, Z. Zdravkova, Indian J. Phys 73B (1999) 679.

[19] A. John, S. Devanarayanan, M. Watanabe, Spectrochim. Acta 56A (2000) 877.

[20] A. John, D. Philip, A.K. Idrissi, G. Keresztury, S. Devanarayanan, J Raman Spectrosc., in press.

[21] N. Stock, W. Schnick, Z. Naturfosch 52B (1997) 251.

[22] N. Stock, W. Schnick, Acta Cryst. C53 (1997) 532.

[23] N. Stock, B. Jurgens, W. Schnick, Laboratorium for Anorganische Chemie Universitat, D-95440 Bayreuth, Germany, pesonal communication. 
[24] N. Stock, W. Schnick, Acta Cryst. C54 (1998) 171.

[25] W.G. Fateley, F.R. Dollish, N.T. McDevitt, F.F. Bentley, Infrared and Raman Selection Rules for Molecules and Lattice Vibrations: The Correlation Method, Wiley Interscience, New York, 1972.

[26] K. Nakamoto, Infrared and Raman Spectra of Inorganic and Coordination Compounds, fifth ed., Wiley, New York, 1997 Part A.

[27] R.Ya Melnikova, V.N. Korzhuev, E.A. Prodan, I.E. Malashonok, J. Appl. Spectrosc. 41 (1984) 1147.

[28] T.C. Waddington, J. Chem. Soc. (1958) 4340.

[29] P.K. Acharya, P.S. Narayanan, Indian J. Pure Appl. Phys. 11 (1973) 574.

[30] I.A. Oxton, O. Knop, M. Falk, Can. J. Chem. 53 (1975) 3394.
[31] G.J. Kearly, I.A. Oxton, Adv. Infrared Raman Spectrosc. 10 (1983) 111.

[32] R. Haresh, P. Rajagopal, G. Aruldhas, Spectrochim. Acta 48A (1992) 1453.

[33] A. Rulmont, R. Cahay, M. Liegeois-Duyckaerts, P. Tarte, Eur. J. Solid State Inorg. Chem. 28 (1991) 207.

[34] I.H. Joe, G. Aruldhas, G. Kersztury, J. Raman Spectrosc. 22 (1991) 537.

[35] V.S. Jayakumar, Ph.D Thesis, Univerity of Kerala, India, 1993.

[36] M. Harcharras, A. Ennaciri, A. Rulmont, B. Gilbert, Spectrochim. Acta 53A (1997) 345.

[37] A.N. Lazarev, Vibrational Spectra and Structure of Silicates, English Translation, Consultant Bureau, New York, 1972. 